\title{
Genome-Wide Association Studies of Cardiovascular Disease in European and Non-European Populations
}

\author{
Ruth McPherson
}

Published online: 12 February 2014

(C) Springer Science + Business Media New York 2014

\begin{abstract}
Genome-wide association studies (GWASs) for coronary artery disease (CAD) have identified more than 40 variants robustly associated with CAD risk in European white populations. Overall, the majority of GWAS-identified CAD loci are in non-coding regions of the genome and may encompass multiple signals of variable effect. Most of these are not associated with conventional risk factors but highlight novel pathways, including extracellular matrix integrity, proliferative response to cellular injury and immune regulation. Many but not all of these CAD-associated loci have been found to replicate in South Asian and East Asian populations although with variable effect size in South Asians. The significantly shorter haplotype blocks in populations of African ethnicity may be helpful in fine mapping association signals identified in European populations and also in identifying new signals that may be ethnic specific. However, differential linkage disequilibrium between tag SNPs and functional variants contribute significantly to diluting the effect sizes, and few significant CAD loci identified in European populations have been replicated in African Americans.
\end{abstract}

Keywords GWAS - Coronary artery disease . Cardiovascular disease $\cdot$ European population $\cdot$ NonEuropean population · African American · South Asian . Review

R. McPherson ( $\square)$

Atherogenomics Laboratory, Division of Cardiology, University of Ottawa Heart Institute, 40 Ruskin St-H2403, Ottawa, ON K1Y 4W7, Canada

e-mail: rmcpherson@ottawaheart.ca

\section{Introduction}

In the past 7 years, genome-wide association studies (GWAS) have been successful in mapping the chromosomal location of numerous common coronary artery disease (CAD)-associated alleles. Although important, these explain only approximately $10 \%$ of the predicted heritable risk for CAD. The age-specific incidence of CAD in participants in the Framingham Offspring Study was increased approximately two-fold in subjects with a family history of premature disease after adjustment for conventional CAD risk factors [1]. The Swedish Twin registry followed close to 21,000 subjects for over 35 years and estimated the heritability of fatal CAD events to be 0.57 for men and 0.38 for women, with heritable effects being most manifest in younger individuals [2]. Similarly several GWA studies have demonstrated not unexpectedly that the genetic influence is greatest for early onset CAD events [3•].

This recent progress in the genetics of CAD and other complex disease has been driven by technological advances including high-throughput DNA microarray technology, the availability of 1,000 Genomes data sets to facilitate imputation of less common variants, and a number of bioinformatic approaches including pathway analysis for GWAS. In the commercial arrays used for GWAS, single nucleotide polymorphisms (SNPs; generally 0.5-1 M) are used to tag common variation (SNPs with a frequency of $\geq 5 \%$ ) across the human genome. Importantly, these are 'tag' SNPs that point to a causative locus but are rarely in themselves functional variants. This approach makes use of linkage disequilibrium (LD), that is, the nonrandom coinheritance of genetic variants across the human genome.

Segments of DNA known as haplotype blocks are shared within ancestral groups. Due to the recent migration of 
humans into Europe, individuals of European ancestry have more correlated SNPs and longer haplotype blocks as compared to populations of African ancestry [4-6]. As reported by Hinds et al., the average haplotype block is $\sim 20.7 \mathrm{~kb}$ in European whites, $\sim 8.8 \mathrm{~kb}$ in African Americans and $\sim 25.2 \mathrm{~kb}$ in Han Chinese. Thus, fewer 'tag' SNPs are required for genotyping a population of European or East Asian versus African ancestry. If causal variants are shared across different populations, by taking advantage of differences in LD and allele frequencies, trans-ethnic mapping could facilitate identification of causal variants underlying disease susceptibility. In particular, the significantly shorter haplotype blocks in African American populations can be helpful in fine mapping association signals identified in European populations and also in identifying new signals that may be ethnic specific [7].

Although most GWAS for CAD have been carried out in European white populations, smaller but important studies have been performed in East Asian, South Asian and African American populations (Table 1).

\section{GWAS in European White Populations}

The first robust association with CAD identified by the GWAS approach, a 53-kb linkage disequilibrium block containing multiple highly correlated single nucleotide polymorphisms (SNPs) at the 9p21.3 locus, was identified by three independent groups in 2007 [8-10]. The early discovery of this risk locus was facilitated by its large effect size and high-risk allele frequency (approximately 0.48). Approximately $25 \%$ of Europeans carry two copies of the risk allele and have a $50 \%$ increased risk of CAD in general and an even greater increased risk of premature CAD. This was demonstrated in the large Coronary Artery Disease Genome-wide Replication and Meta-Analysis (CARDIoGRAM) of several GWASs, in which the allelespecific odds ratio (OR) for CAD in subjects with $\mathrm{CAD}$ onset before the age of 50 years was 1.41 [95\% confidence interval (CI) 1.34-1.48], significantly greater than that for older individuals (OR 1.24; $95 \%$ CI 1.20-1.28) [3•]. The 9 p21 locus is also associated with the overall severity of atherosclerosis [11, 12], with a substantially higher risk allele frequency in subjects with multi-vessel disease. Notably, the risk conferred by this locus is independent of known risk factors including diabetes, plasma lipids, blood pressure, adiposity, inflammatory markers, sex and age. Other vascular phenotypes associated with the 9p21 risk alleles include carotid atherosclerosis [13], stroke [14] [15] and peripheral arterial disease [16], as well as abdominal aortic aneurysm [17] and intracranial aneurysms [18], the latter highlighting possible effects on vascular remodeling pathways as well as platelet reactivity [19]. There is also a surprising and confirmed association with periodonitis [20, 21].

The causative alleles at 9p21.3 have not been identified. Fine mapping efforts, including targeted resequencing at high coverage and 1,000 Genome imputation, have failed to identify stronger associations than the original GWAS signals [22, 23].

Although the risk region is devoid of protein coding genes, it overlaps a large nonprotein coding RNA, termed "CDKN2BAS (ANRIL)," and lies adjacent to a cluster of cell cycle-regulating tumor-suppressor genes, including the cyclin-dependent kinase inhibitors, $C D K N 2 A$ and $C D K N 2 B$, and SNPs associated with CAD have been found to associate with the expression of each of these genes [2325].

Since the 9p21 discovery in 2007, large meta-analyses of additional GWASs, the majority of which have been conducted in European populations, have identified over 35 additional loci of smaller effect size but with genome-wide $\left(P<5 \times 10^{-8}\right)$ significance. This success has been built on large collaborative efforts, including the Myocardial Infarction Genomics Consortium [26], the CARDIoGRAM consortium [3•], the Coronary Artery Disease (C4D) Genetics Consortium [27], CARDIoGRAMplusC4D [28•] and others.

Novel CAD risk loci identified include genes playing known roles in lipoprotein metabolism, hypertension and other CAD-associated phenotypes, but importantly include several novel loci of unknown function. Highlighting the discovery potential of the GWAS approach, the majority of risk loci harbor genes not previously known to be involved in atherosclerosis or plaque rupture. Several risk regions such as $A B O$ and $\mathrm{SH} 2 \mathrm{~B} 3$ exhibit pleiotropic effects, associating with multiple $\mathrm{CAD}$ and non-CAD-related phenotypes. Overall, as might be expected for common variants affecting a complex trait such as CAD, the effect sizes are small. With the exception of the 9p21.3 locus, the LPA gene [29] encoding lipoprotein(a), and a region of unknown function at $6 \mathrm{p} 24$, the allele-specific ORs for CAD of replicated loci are less than 1.15.

\section{Studies in East Asian Populations}

In general, most of the disease-related GWAS loci discovered in Europeans have been extensively replicated in populations of European and East Asian ancestry. Marigorta and Navarro [30•] recently demonstrated a strong and significant correlation of odds ratios of specific SNPs for CAD and 27 other diseases across European and East Asian samples, indicating that in general causal variants are shared between the two populations. The SNPs that failed 


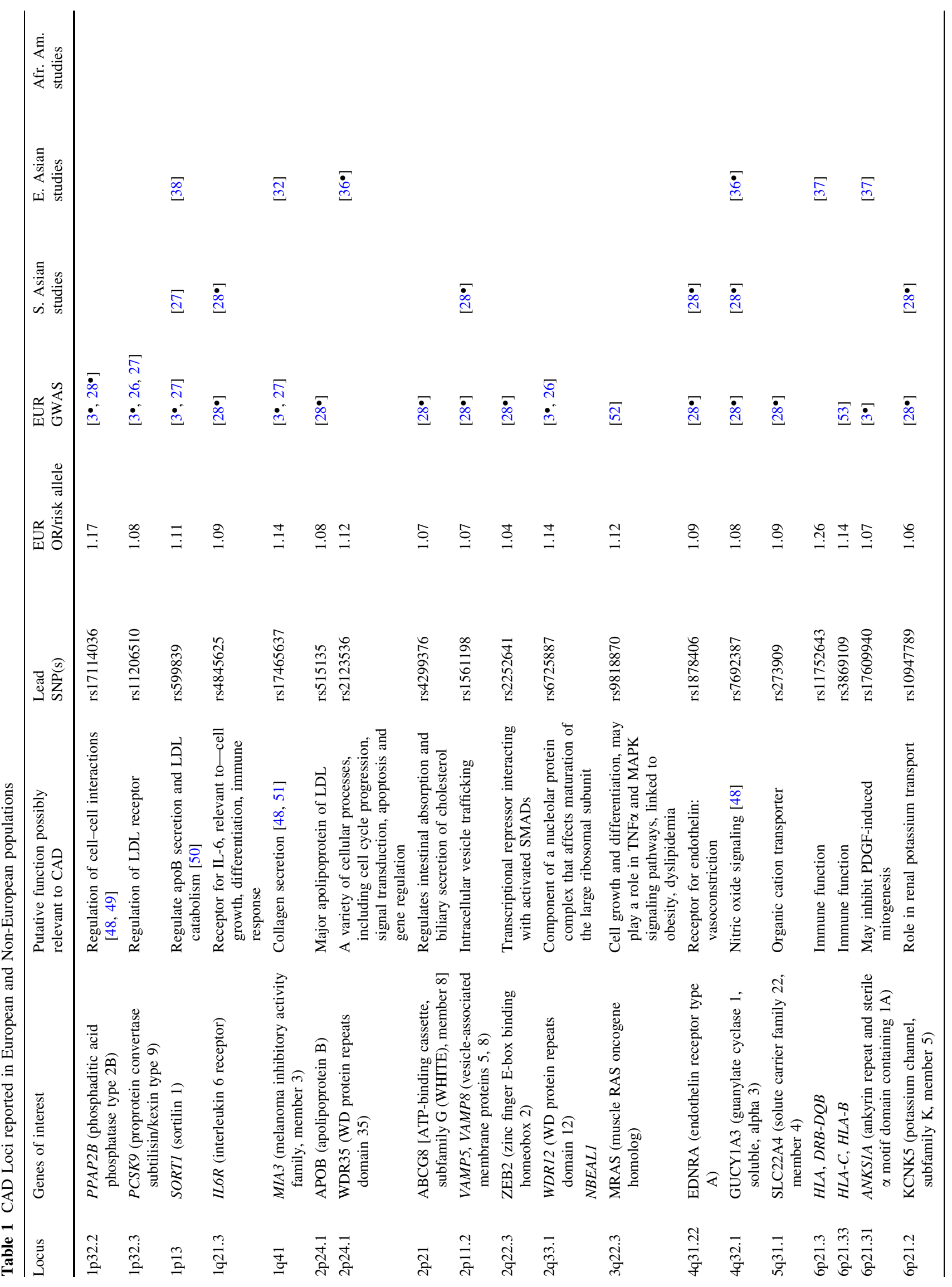




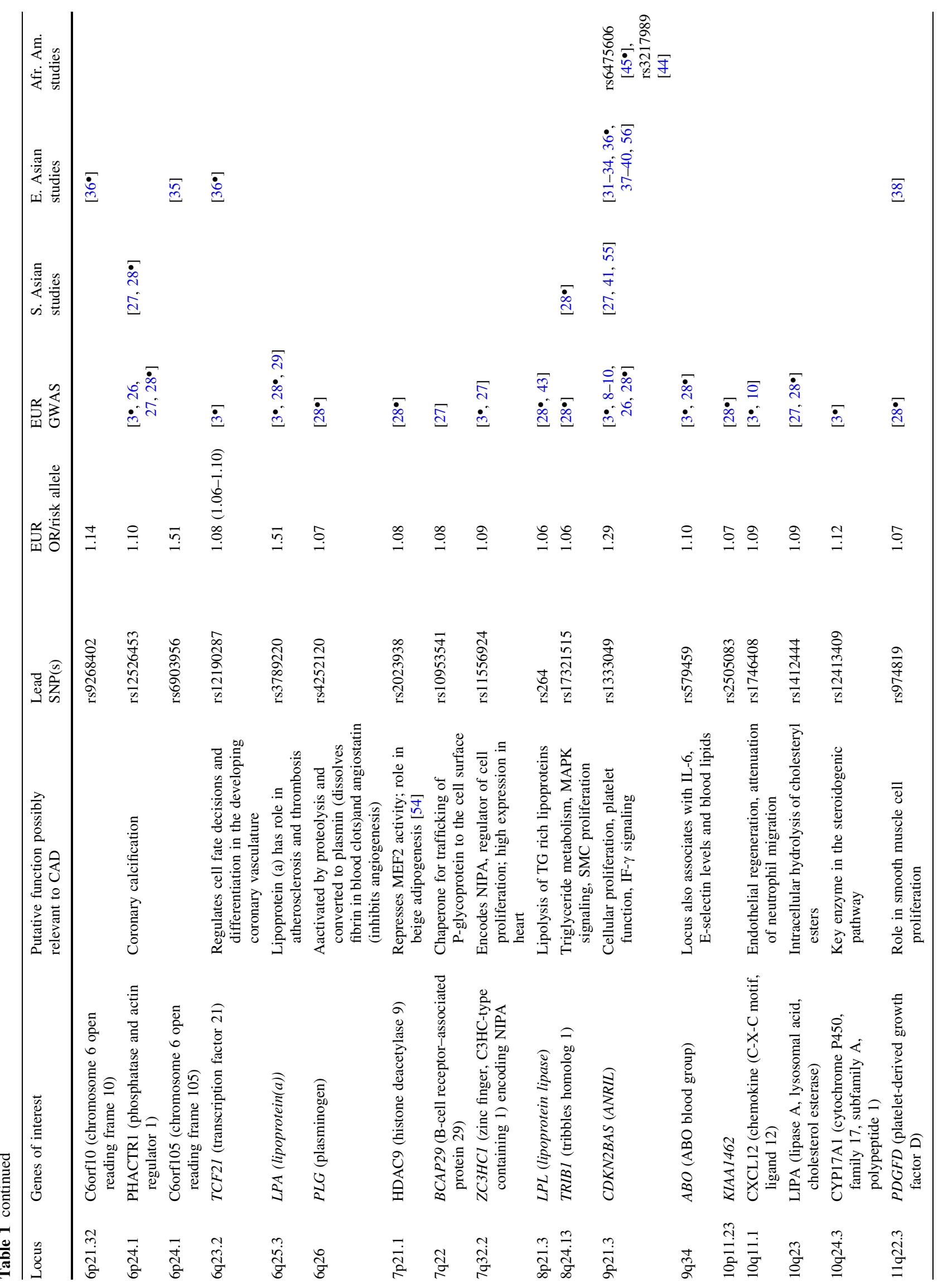




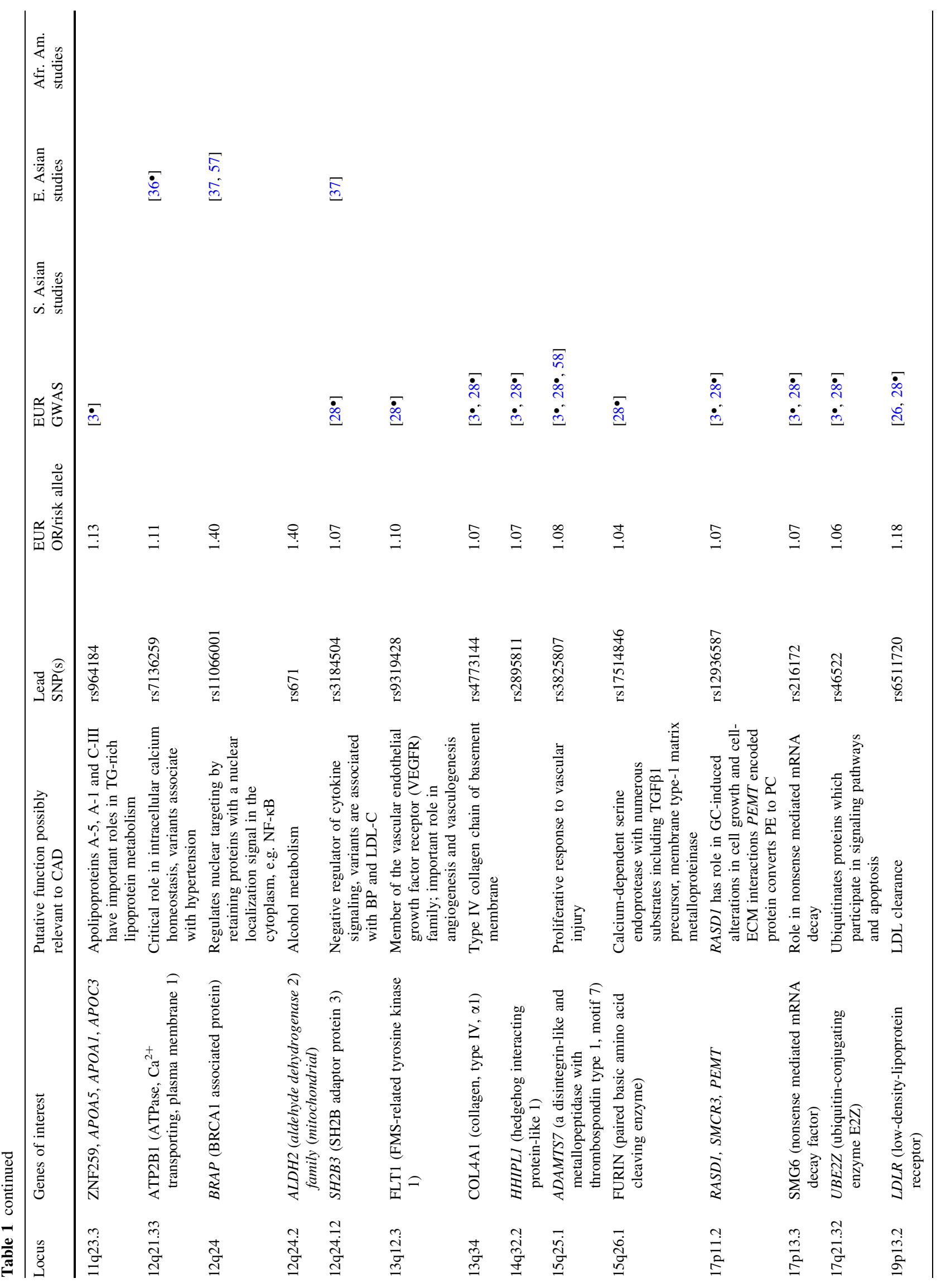


to replicate in East Asian populations mapped to genomic regions with differing linkage disequilibrium patterns.

Shortly after the 9p21.3 finding in Europeans was reported, three groups replicated the association with CAD in Chinese Han [31], Japanese [32, 33] and Korean [34] populations. Fewer large GWAS studies for CAD have been carried out in East Asian as compared to European populations. In 2011, Wang et al. [35] reported a threestage GWAS for CAD in the Chinese Han population. The numbers were relatively small, consisting of a total of 3,470 cases and 4,583 controls. A novel association between rs6903956 near C6orf105 on chromosome 6p24.1 was found. Of note, the MAF of this SNP is higher in the HapMap European (CEU) population (28 vs. $6.7 \%$ in Chinese), and no association with CAD has been reported in European GWAS.

In 2012, Lu et al. [36 ] performed a meta-analysis of two GWAS of CAD in Han Chinese, consisting of 1,515 cases and 5,019 controls with replication in 15,460 cases and 11,472 controls. Four loci originally identified in European populations were confirmed, including 9p21.3, PHACTR1, TCF1 and C12orf51, and four new loci identified, including WDR35, GUCY1A3 (later confirmed in CARDIoGRAMplusC4D [28•]) and C6orf10-BTNL2 and ATP2B1. In the same year, Takeuchi et al. [37] reported on a multistage GWA study performed in the Japanese. The discovery phase consisted of a GWAS in 806 cases and 1,337 controls with wet lab replication of 12 SNPs in 3,052 cases and 6,335 controls. Three loci achieved significance: $12 \mathrm{q} 24$ near $B R A P$ and $A L D H 2, H L A, D R B-D Q B$ on $6 \mathrm{p} 21$ and 9p21.3.

More recently (2013), a two-stage CAD GWAS was reported in Korean and Japanese populations [38]. The discovery sample included 2,123 cases and 3,591 controls recruited in Korea with wet lab replication in 3,052 cases and 4,976 controls in Japan. CAD association was replicated for three GWAS-identified loci identified in European populations including the SORT1 locus at $1 \mathrm{p} 13.3$ (rs599839), the 9p21.3 CDKN2BAS locus (rs4977574) and $P D G F D$ at $11 \mathrm{q} 22.3$ (rs974819).

Guo et al. [39] recently investigated the association of the 9p21.3 locus with CAD in 12 case-control studies of East Asians and undertook a meta-analysis for effect size, heterogeneity, publication bias and strength of evidence. SNPs (rs1333049, rs2383206 and/or rs10757278) were genotyped in 12 case-control studies involving a total of 9,813 patients and 10,710 controls. The mean summary odds ratios for these three 9p21.3 SNPs was 1.29 , similar to that observed in European populations. In accord with this finding, a large meta-analysis by Dong et al. [40] reported a similar allele-specific odds ratio for the lead 9p21 CAD risk SNP in East Asian and European populations. 
Overall, the GWAS and candidate loci replication studies in East Asian populations have successfully replicated many of the loci identified in much larger European studies. Novel loci, e.g., ATP2B1, are of interest and await confirmation in larger studies.

\section{Studies in South Asian Populations}

There have been few studies reported in South Asians despite the apparently higher risk for CAD than would be anticipated based on conventional risk factors. In 2010, Saleheen et al. [41] examined the relationship of 9p21.3 risk variants to acute MI in a case-control study in Pakistan consisting of 1,851 cases and 1,903 controls. For the Pakistani population, the odds ratio of the lead SNP, rs1333049, was 1.13 (CI 1.05-1.22) as compared to 1.31 (1.26-1.37) in a meta-analysis of Europeans.

In 2011, the IBC $50 \mathrm{~K}$ CAD Consortium [42] conducted a large candidate gene study of CAD susceptibility, including analysis of 49,094 genetic variants in 2,100 genes using a customized gene array in 15,596 CAD cases and 34,992 controls (11,202 cases and 30,733 controls of European descent; 4,394 cases and 4,259 controls of South Asian origin). Associations of several previously known CAD susceptibility loci including 9p21.3, LPA, COL4A1/ COLAA2, ZC3HCl and CYP17A1 were confirmed. Of note, associations in South Asians did not differ appreciably from those in Europeans, except for 9p21.3 exhibiting an allele-specific odds ratio of 1.14 versus 1.27 ( $P$ for heterogeneity $=0.003$ ).

The first published GWAS for CAD including a substantial number of South Asians was by the C4D Consortium and included a discovery data set of 15,420 CAD cases, of which 6,996 were South Asians [27]. Their replication sample included 21,408 CAD cases with only 3,359 of South Asian descent. A total of 11 previously reported common variants for $\mathrm{CAD}$ were confirmed in this study with directionally consistent effects in European and South Asian populations for all 11 loci. However, the odds ratio for several of these including 9p21.3, SORT1 and WDR12 was somewhat lower in the South Asian studies. Five new loci achieved genome-wide significance, including LIPA on 10q23, PDGFD on 11q22, a locus containing multiple genes on 7q22, KIAA1462 on 10p11 and ADAMTS7. More recently, the CARDIoGRAMplusC4D Consortium carried out an association analysis in 63,746 CAD cases and 130,681 controls identifying 15 novel loci reaching genome-wide significance [28•]. This study included additional South Asian cohorts, but subgroup analysis by ethnicity was not reported.

In summary, despite smaller data sets, there is general concordance in the directional effects of CAD risk alleles identified in European populations on CAD risk in South Asians. It is of interest that in contrast to the similar effect size reported in European and East Asian populations, the effect size of many risk alleles appears attenuated in South Asians, possibly due to interaction with unknown genetic or environmental risk modifiers. Other larger GWA studies in this population are underway.

\section{African American Populations}

In the recent study by Marigorta and Navarro [30•], SNPs associated with 28 disease phenotypes in Europeans exhibited low replication in individuals of African ancestry despite an average statistical power of $59.2 \%$. This might suggest limited sharing of causal variants between Europeans and Africans as compared to East Asians. However, given the lower level of $\mathrm{LD}$ in African populations, potentially shared casual variants may not be tagged by the index SNP identified in European studies [30•].

In general, CAD-associated loci identified in European populations have failed to replicate or shown attenuated effects in black populations. In the PAGE multiethnic study [43], the association of 13 published CAD SNPs with incident CAD events over a 9-16-year follow-up period was examined in four large US prospective cohorts, including 26,617 white individuals (6,626 events), 8,018 black individuals (914 events), 1,903 Hispanic individuals (113 events), 3,669 American Indian individuals (595 events) and 885 Asian/Pacific Islander individuals (66 events). In white subjects, 9 of the 13 loci were statistically associated with incident CAD events including 9p21, 16q23.1, 6p24.1, 2q36.3, MTHFD1L, APOE, ZNF627, CXCL12 and LPL. Notably, despite an adequate sample size, these SNPs were not associated with CAD in black participants, and 9p21.3 reached nominal significance in the American Indian but not the other small populations.

Kral et al. [44] sought to further characterize the role of genetic variants in 9p21.3 in African American individuals. Healthy siblings of African American patients with documented CAD $<60$ years of age (548 sibling pairs) were genotyped and followed for incident CAD for up to 17 years. Of 86 SNPs across the 9p21.3 region, a single SNP within the $3^{\prime} \mathrm{UTR}$ of the $C D K N 2 B$ gene met stringent criteria for statistical significance, including permutationbased evaluations. This variant, rs3217989, with a MAF of 0.242 , was associated with protection against CAD (OR $0.19,95 \%$ CI $0.07-0.50, P=0.0008$ ) and in this study replicated in a combined analysis of two additional case/ control studies of prevalent CAD/MI in African Americans $(n=990, P=0.024$, OR $0.779,95 \%$ CI $0.626-0.968)$. This was the first report of a CAD association signal in a population of African ancestry within the 9p21 locus. 
Although common in the African American population, rs3217989 has an MAF of $<0.01$ in European white and Asian populations, and this finding remains to be confirmed in independent African American cohorts.

The largest GWAS for CAD-related complex traits in African Americans was reported by Lettre et al. [45•] in 2011. The NHLBI CARe study consisted of 8,090 subjects from five population-based cohorts: Atherosclerosis Risk in Communities (ARIC; $N=3,269$ ), Coronary Artery Risk Development in young Adults (CARDIA; $N=1,209$ ), Cleveland Family Study (CFS; $N=704$ ), Jackson Heart Study (JHS; $N=2,200$ ) and Multi-Ethnic Study of Atherosclerosis (MESA; $N=1,737$ ), genotyped on the Affymetrix 6.0 array. However, the number of CAD cases was relatively small. In this study the authors took advantage of the shorter LD blocks in African Americans in an attempt to fine-map some of the associations previously reported in Europeans. To do this, they evaluated SNPs that were correlated with the index SNP in HapMap CEU $\left(r^{2}>0.5\right)$ but largely uncorrelated with it in the HapMap African population (YRI, $r^{2}<0.1$ ). For many traits, the same signals were responsible for the associations in Europeans and African Americans with important exceptions where the predominant association signals were at SNPs strongly correlated with the index SNPs in HapMap CEU but not with the index SNPs in HapMap YRI including at the 9p21.3 locus for CAD.

The only 9p21.3 SNP previously reported in European populations to reach significance in CARe was rs6475606 at 9p21 position 22081850 in intron 12 of CDKN2BAS (ANRIL) (replication $P$ value 6.4E-4; adds ratio 2.0). Of interest, rs6475606 lies within a smaller HapMap YRI LD block (43 kb) as compared to the major 128-kb LD block defined in the HapMap CEU population. The frequency of the effect allele of rs6475606 was 0.109 in this African American population versus 0.008 in HapMap YRI and 0.52 in HapMap CEU data sets. It was hoped that this finding might define a smaller genomic interval within the 9p21 locus to search for causative alleles. Several linked SNPs overlap DNAse protected sites, harbor enhancer histone marks and are predicted to alter transcription factor binding motifs.

In a more recent study of the genetics of coronary artery calcification (CAC) [46], 166 SNPs in the 9p21.3 region significant for CAD and CAC for EUR population were queried. Of these, 24 SNPs displayed nominal evidence for association $(P \leq 0.05)$. Ten of these 24 SNPs localized within the 43-kb HapMap YRI region and 14 in the $128-\mathrm{kb}$ HapMap CEU LD block. However, neither the strongest 9p21.3 EUR SNPs for CAC (rs1333049) nor CAD (rs4977574) in Europeans reached significance in the African American population. The peak CAC association was within the smaller 43-kb LD block at rs16905644 (effect allele frequency 0.11, Bonferroni corrected
$P=0.0068)$. No signal for CAC was apparent for either rs6475606 [44] or rs3217989 [45•], reported to associate with CAD in African Americans by Kral et al. [44] and Lettre et al. [45•], respectively.

\section{Conclusion}

In conclusion, despite the high prevalence of CAD among African Americans and the potential advantage of interrogating their shorter LD blocks for fine mapping of previously identified CAD loci, progress has been minor. The two signals reported for CAD at the 9p21.3 locus have not yet achieved replication in independent African American data sets, and other signals for CAD per se have not been identified, although replication has been achieved for signals associated with discrete CAD risk factors [45॰]. It is possible that the genetic risk for $\mathrm{CAD}$ relates more strongly to genetic contribution to discrete risk factors more common in African Americans including hypertension and obesity. Multiple genetic variants of small effect are believed to account for much of the missing heritability of CAD in Europeans, and these may be even greater in number and thus more difficult to detect in populations of African descent.

As Carlson et al. [47••] reported from the Population Architecture using Genomics and Epidemiology (PAGE) study, a consortium of multi-ancestry, population-based studies, $25 \%$ of tag SNPs identified in European GWAS had significantly different effect sizes in non-European populations, and this was particularly evident in African American cohorts. They demonstrated that that differential LD between tag SNPs and functional variants within populations contributed significantly to diluting the effect sizes in this population [47••]. Larger studies in both African American and South Asian populations are underway, and other approaches such as pathway analysis for GWAS may provide new information relevant to the biology of CAD in these populations.

Disclosure R. McPherson declares no conflicts of interest.

Human and Animal Rights and Informed Consent This article does not contain any studies with human or animal subjects performed by any of the author.

\section{References}

Papers of particular interest, published recently, have been highlighted as:

- Of importance

•• Of major importance

1. Lloyd-Jones DM, Nam BH, D’Agostino RB Sr, Levy D, Murabito JM, Wang TJ, Wilson PW, O'Donnell CJ. Parental 
cardiovascular disease as a risk factor for cardiovascular disease in middle-aged adults: a prospective study of parents and offspring. JAMA. 2004;291:2204-11.

2. Zdravkovic S, Wienke A, Pedersen NL, Marenberg ME, Yashin AI, de Faire U. Heritability of death from coronary heart disease: a 36-year follow-up of 20966 Swedish twins. J Intern Med. 2002;252:247-54.

3. - Schunkert H, Konig IR, Kathiresan S, Reilly MP, Assimes TL, Holm H, Preuss M, Stewart AF, Barbalic M, Gieger C, Absher D, Aherrahrou Z, Allayee H, Altshuler D, Anand SS, Andersen K, Anderson JL, Ardissino D, Ball SG, Balmforth AJ, Barnes TA, Becker DM, Becker LC, Berger K, Bis JC, Boekholdt SM, Boerwinkle E, Braund PS, Brown MJ, Burnett MS, Buysschaert I, Carlquist JF, Chen L, Cichon S, Codd V, Davies RW, Dedoussis G, Dehghan A, Demissie S, Devaney JM, Diemert P, Do R, Doering A, Eifert S, Mokhtari NE, Ellis SG, Elosua R, Engert JC, Epstein SE, de FU, Fischer M, Folsom AR, Freyer J, Gigante B, Girelli D, Gretarsdottir S, Gudnason V, Gulcher JR, Halperin E, Hammond N, Hazen SL, Hofman A, Horne BD, Illig T, Iribarren C, Jones GT, Jukema JW, Kaiser MA, Kaplan LM, Kastelein JJ, Khaw KT, Knowles JW, Kolovou G, Kong A, Laaksonen R, Lambrechts D, Leander K, Lettre G, Li M, Lieb W, Loley C, Lotery AJ, Mannucci PM, Maouche S, Martinelli N, McKeown PP, Meisinger C, Meitinger T, Melander O, Merlini PA, Mooser V, Morgan T, Muhleisen TW, Muhlestein JB, Munzel T, Musunuru K, Nahrstaedt J, Nelson CP, Nothen MM, Olivieri O, Patel RS, Patterson CC, Peters A, Peyvandi F, Qu L, Quyyumi AA, Rader DJ, Rallidis LS, Rice C, Rosendaal FR, Rubin D, Salomaa V, Sampietro ML, Sandhu MS, Schadt E, Schafer A, Schillert A, Schreiber S, Schrezenmeir J, Schwartz SM, Siscovick DS, Sivananthan M, Sivapalaratnam S, Smith A, Smith TB, Snoep JD, Soranzo N, Spertus JA, Stark K, Stirrups K, Stoll M, Tang WH, Tennstedt S, Thorgeirsson G, Thorleifsson G, Tomaszewski $\mathrm{M}$, Uitterlinden AG, van Rij AM, Voight BF, Wareham NJ, Wells GA, Wichmann HE, Wild PS, Willenborg C, Witteman JC, Wright BJ, Ye S, Zeller T, Ziegler A, Cambien F, Goodall AH, Cupples LA, Quertermous T, Marz W, Hengstenberg C, Blankenberg S, Ouwehand WH, Hall AS, Deloukas P, Thompson JR, Stefansson K, Roberts R, Thorsteinsdottir U, O'Donnell CJ, McPherson R, Erdmann J, Samani NJ. Large-scale association analysis identifies 13 new susceptibility loci for coronary artery disease. Nat Genet. 2011;43:333-8. The first large meta-analysis of multiple GWAS for CAD identifying 13 new loci.

4. Lonjou C, Zhang W, Collins A, Tapper WJ, Elahi E, Maniatis N, Morton NE. Linkage disequilibrium in human populations. Proc Natl Acad Sci USA. 2003;100:6069-74.

5. Campbell MC, Tishkoff SA. African genetic diversity: implications for human demographic history, modern human origins, and complex disease mapping. Annu Rev Genomics Hum Genet. 2008;9:403-33.

6. Hinds DA, Stuve LL, Nilsen GB, Halperin E, Eskin E, Ballinger DG, Frazer KA, Cox DR. Whole-genome patterns of common DNA variation in three human populations. Science. 2005;307:1072-9.

7. Edwards SL, Beesley J, French JD, Dunning AM. Beyond GWASs: illuminating the dark road from association to function. Am J Hum Genet. 2013;93:779-97.

8. McPherson R, Pertsemlidis A, Kavaslar N, Stewart A, Roberts R, Cox DR, Hinds DA, Pennacchio LA, Tybjaerg-Hansen A, Folsom AR, Boerwinkle E, Hobbs HH, Cohen JC. A common allele on chromosome 9 associated with coronary heart disease. Science. 2007;316:1488-91.

9. Helgadottir A, Thorleifsson G, Manolescu A, Gretarsdottir S, Blondal T, Jonasdottir A, Jonasdottir A, Sigurdsson A, Baker A, Palsson A, Masson G, Gudbjartsson DF, Magnusson KP, Andersen K, Levey AI, Backman VM, Matthiasdottir S,
Jonsdottir T, Palsson S, Einarsdottir H, Gunnarsdottir S, Gylfason A, Vaccarino V, Hooper WC, Reilly MP, Granger CB, Austin H, Rader DJ, Shah SH, Quyyumi AA, Gulcher JR, Thorgeirsson G, Thorsteinsdottir U, Kong A, Stefansson K. A common variant on chromosome 9p21 affects the risk of myocardial infarction. Science. 2007;316:1491-3.

10. Samani NJ, Erdmann J, Hall AS, Hengstenberg C, Mangino M, Mayer B, Dixon RJ, Meitinger T, Braund P, Wichmann HE, Barrett JH, Konig IR, Stevens SE, Szymczak S, Tregouet DA, Iles MM, Pahlke F, Pollard H, Lieb W, Cambien F, Fischer M, Ouwehand W, Blankenberg S, Balmforth AJ, Baessler A, Ball SG, Strom TM, Braenne I, Gieger C, Deloukas P, Tobin MD, Ziegler A, Thompson JR, Schunkert H. Genomewide association analysis of coronary artery disease. $N$ Engl $J$ Med. 2007;357:443-53.

11. Dandona S, Stewart AF, Chen L, Williams K, So D, O'Brien E, Glover C, Lemay M, Assogba O, Vo L, Wang YQ, Labinaz M, Wells GA, McPherson R, Roberts R. Gene dosage of the common variant $9 \mathrm{p} 21$ predicts severity of coronary artery disease. J Am Coll Cardiol. 2010;56:479-86.

12. Chan K, Patel RS, Newcombe P, Nelson CP, Qasim A, Epstein SE, Burnett S, Vaccarino VL, Zafari AM, Shah SH, Anderson JL, Carlquist JF, Hartiala J, Allayee H, Hinohara K, Lee BS, Erl A, Ellis KL, Goel A, Schaefer AS, El Mokhtari NE, Goldstein BA, Hlatky MA, Go AS, Shen GQ, Gong Y, Pepine C, Laxton RC, Whittaker JC, Tang WH, Johnson JA, Wang QK, Assimes TL, Nothlings U, Farrall M, Watkins H, Richards AM, Cameron VA, Muendlein A, Drexel H, Koch W, Park JE, Kimura A, Shen WF, Simpson IA, Hazen SL, Horne BD, Hauser ER, Quyyumi AA, Reilly MP, Samani NJ, Ye S. Association between the chromosome 9p21 locus and angiographic coronary artery disease burden: a collaborative meta-analysis. J Am Coll Cardiol. 2013;61:957-70.

13. Ye S, Willeit J, Kronenberg F, Xu Q, Kiechl S. Association of genetic variation on chromosome 9p21 with susceptibility and progression of atherosclerosis: a population-based, prospective study. J Am Coll Cardiol. 2008;52:378-84.

14. Smith JG, Melander O, Lovkvist H, Hedblad B, Engstrom G, Nilsson P, Carlson J, Berglund G, Norrving B, Lindgren A. Common genetic variants on chromosome 9p21 confers risk of ischemic stroke: a large-scale genetic association study. Circ Cardiovasc Genet. 2009;2:159-64.

15. Anderson CD, Biffi A, Rost NS, Cortellini L, Furie KL, Rosand J. Chromosome 9p21 in ischemic stroke: population structure and meta-analysis. Stroke. 2010;41:1123-31.

16. Cluett C, McDermott MM, Guralnik J, Ferrucci L, Bandinelli S, Miljkovic I, Zmuda JM, Li R, Tranah G, Harris T, Rice N, Henley W, Frayling TM, Murray A, Melzer D. The 9p21 myocardial infarction risk allele increases risk of peripheral artery disease in older people. Circ Cardiovasc Genet. 2009;2:347-53.

17. Bown MJ, Braund PS, Thompson J, London NJ, Samani NJ, Sayers RD. Association between the coronary artery disease risk locus on chromosome 9p21.3 and abdominal aortic aneurysm. Circ Cardiovasc Genet. 2008;1:39-42.

18. Helgadottir A, Thorleifsson G, Magnusson KP, Gretarsdottir S, Steinthorsdottir V, Manolescu A, Jones GT, Rinkel GJ, Blankensteijn JD, Ronkainen A, Jaaskelainen JE, Kyo Y, Lenk GM, Sakalihasan N, Kostulas K, Gottsater A, Flex A, Stefansson H, Hansen T, Andersen G, Weinsheimer S, Borch-Johnsen K, Jorgensen T, Shah SH, Quyyumi AA, Granger CB, Reilly MP, Austin H, Levey AI, Vaccarino V, Palsdottir E, Walters GB, Jonsdottir T, Snorradottir S, Magnusdottir D, Gudmundsson G, Ferrell RE, Sveinbjornsdottir S, Hernesniemi J, Niemela M, Limet R, Andersen K, Sigurdsson G, Benediktsson R, Verhoeven EL, Teijink JA, Grobbee DE, Rader DJ, Collier DA, Pedersen O, Pola R, Hillert J, Lindblad B, Valdimarsson EM, Magnadottir 
HB, Wijmenga C, Tromp G, Baas AF, Ruigrok YM, van Rij AM, Kuivaniemi H, Powell JT, Matthiasson SE, Gulcher JR, Thorgeirsson G, Kong A, Thorsteinsdottir U, Stefansson K. The same sequence variant on 9p21 associates with myocardial infarction, abdominal aortic aneurysm and intracranial aneurysm. Nat Genet. 2008;40:217-24.

19. Musunuru K, Post WS, Herzog W, Shen H, O'Connell JR, McArdle PF, Ryan KA, Gibson Q, Cheng YC, Clearfield E, Johnson AD, Tofler G, Yang Q, O'Donnell CJ, Becker DM, Yanek LR, Becker LC, Faraday N, Bielak LF, Peyser PA, Shuldiner AR, Mitchell BD. Association of single nucleotide polymorphisms on chromosome 9p21.3 with platelet reactivity: a potential mechanism for increased vascular disease. Circ Cardiovasc Genet. 2010;3:445-53.

20. Ernst FD, Uhr K, Teumer A, Fanghanel J, Schulz S, Noack B, Gonzales J, Reichert S, Eickholz P, Holtfreter B, Meisel P, Linden GJ, Homuth G, Kocher T. Replication of the association of chromosomal region 9p21.3 with generalized aggressive periodontitis $(\mathrm{gAgP})$ using an independent case-control cohort. BMC Med Genet. 2010;11:119.

21. Schaefer AS, Richter GM, Groessner-Schreiber B, Noack B, Nothnagel M, El Mokhtari NE, Loos BG, Jepsen S, Schreiber S. Identification of a shared genetic susceptibility locus for coronary heart disease and periodontitis. PLoS Genet. 2009;5:e1000378.

22. Shea J, Agarwala V, Philippakis AA, Maguire J, Banks E, Depristo M, Thomson B, Guiducci C, Onofrio RC, Kathiresan S, Gabriel S, Burtt NP, Daly MJ, Groop L, Altshuler D. Comparing strategies to fine-map the association of common SNPs at chromosome 9p21 with type 2 diabetes and myocardial infarction. Nat Genet. 2011;43:801-5.

23. Johnson AD, Hwang SJ, Voorman A, Morrison A, Peloso GM, Hsu YH, Thanassoulis G, Newton-Cheh C, Rogers IS, Hoffmann U, Freedman JE, Fox CS, Psaty BM, Boerwinkle E, Cupples LA, O'Donnell CJ. Resequencing and clinical associations of the 9p21.3 region: a comprehensive investigation in the Framingham heart study. Circulation. 2013;127:799-810.

24. Holdt LM, Beutner F, Scholz M, Gielen S, Gabel G, Bergert H, Schuler G, Thiery J, Teupser D. ANRIL expression is associated with atherosclerosis risk at chromosome 9p21. Arterioscler Thromb Vasc Biol. 2010;30:620-7.

25. Jarinova O, Stewart AF, Roberts R, Wells G, Lau P, Naing T, Buerki C, McLean BW, Cook RC, Parker JS, McPherson R. Functional analysis of the chromosome 9p21.3 coronary artery disease risk locus. Arterioscler Thromb Vasc Biol. 2009;29:1671-7.

26. Kathiresan S, Voight BF, Purcell S, Musunuru K, Ardissino D, Mannucci PM, Anand S, Engert JC, Samani NJ, Schunkert H, Erdmann J, Reilly MP, Rader DJ, Morgan T, Spertus JA, Stoll M, Girelli D, McKeown PP, Patterson CC, Siscovick DS, O'Donnell CJ, Elosua R, Peltonen L, Salomaa V, Schwartz SM, Melander O, Altshuler D, Ardissino D, Merlini PA, Berzuini C, Bernardinelli L, Peyvandi F, Tubaro M, Celli P, Ferrario M, Fetiveau R, Marziliano N, Casari G, Galli M, Ribichini F, Rossi M, Bernardi F, Zonzin P, Piazza A, Mannucci PM, Schwartz SM, Siscovick DS, Yee J, Friedlander Y, Elosua R, Marrugat J, Lucas G, Subirana I, Sala J, Ramos R, Kathiresan S, Meigs JB, Williams G, Nathan DM, MacRae CA, O'Donnell CJ, Salomaa V, Havulinna AS, Peltonen L, Melander O, Berglund G, Voight BF, Kathiresan S, Hirschhorn JN, Asselta R, Duga S, Spreafico M, Musunuru K, Daly MJ, Purcell S, Voight BF, Purcell S, Nemesh J, Korn JM, McCarroll SA, Schwartz SM, Yee J, Kathiresan S, Lucas G, Subirana I, Elosua R, Surti A, Guiducci C, Gianniny L, Mirel D, Parkin M, Burtt N, Gabriel SB, Samani NJ, Thompson JR, Braund PS, Wright BJ, Balmforth AJ, Ball SG, Hall AS, Schunkert H, Erdmann J, Linsel-Nitschke P, Lieb W, Ziegler A, Konig I, Hengstenberg C, Fischer M, Stark K, Grosshennig A, Preuss M,
Wichmann HE, Schreiber S, Schunkert H, Samani NJ, Erdmann J, Ouwehand W, Hengstenberg C, Deloukas P, Scholz M, Cambien F, Reilly MP, Li M, Chen Z, Wilensky R, Matthai W, Qasim A, Hakonarson HH, Devaney J, Burnett MS, Pichard AD, Kent KM, Satler L, Lindsay JM, Waksman R, Epstein SE, Rader DJ, Scheffold T, Berger K, Stoll M, Huge A, Girelli D, Martinelli N, Olivieri O, Corrocher R, Morgan T, Spertus JA, McKeown P, Patterson CC, Schunkert H, Erdmann E, Linsel-Nitschke P, Lieb W, Ziegler A, Konig IR, Hengstenberg C, Fischer M, Stark K, Grosshennig A, Preuss M, Wichmann HE, Schreiber S, Holm H, Thorleifsson G, Thorsteinsdottir U, Stefansson K, Engert JC, Do R, Xie C, Anand S, Kathiresan S, Ardissino D, Mannucci PM, Siscovick D, O’Donnell CJ, Samani NJ, Melander O, Elosua R, Peltonen L, Salomaa V, Schwartz SM, Altshuler D. Genomewide association of early-onset myocardial infarction with single nucleotide polymorphisms and copy number variants. Nat Genet. 2009;41:334-41.

27. Peden JF, Hopewell JC, Saleheen D, Chambers JC, Hager J, Soranzo N, Collins R, Danesh J, Elliott P, Farrall M, Stirrups K, Zhang W, Hamsten A, Parish S, Lathrop M, Watkins HC, Clarke R, Deloukas P, Kooner JS, Goel A, Ongen H, Strawbridge RJ, Heath S, Malarstig A, Helgadottir A, Ohrvik J, Murtaza M, Potter S, Hunt SE, Delepine M, Jalilzadeh S, Axelsson T, Syvanen AC, Gwilliam R, Bumpstead S, Gray E, Edkins S, Folkersen L, Kyriakou T, Franco-Cereceda A, Gabrielsen A, Seedorf U, Eriksson P, Offer A, Bowman L, Sleight P, Armitage J, Peto R, Abecasis G, Ahmed N, Caulfield M, Donnelly P, Froguel P, Kooner AS, McCarthy MI, Samani NJ, Scott J, Sehmi J, Silveira A, Hellenius ML, Van 't Hooft FM, Olsson G, Rust S, Assmann G, Barlera S, Tognoni G, Franzosi MG, Linksted P, Green FR, Rasheed A, Zaidi M, Shah N, Samuel M, Mallick NH, Azhar M, Zaman KS, Samad A, Ishaq M, Gardezi AR, Memon FU, Frossard PM, Spector T, Peltonen L, Nieminen MS, Sinisalo J, Salomaa V, Ripatti S, Bennett D, Leander K, Gigante B, de FU, Pietri S, Gori F, Marchioli R, Sivapalaratnam S, Kastelein JJ, Trip MD, Theodoraki EV, Dedoussis GV, Engert JC, Yusuf S, Anand SS. A genome-wide association study in Europeans and South Asians identifies five new loci for coronary artery disease. Nat Genet. 2011;43:339-344.

28. - Deloukas P, Kanoni S, Willenborg C, Farrall M, Assimes TL, Thompson JR, Ingelsson E, Saleheen D, Erdmann J, Goldstein BA, Stirrups K, Konig IR, Cazier JB, Johansson A, Hall AS, Lee JY, Willer CJ, Chambers JC, Esko T, Folkersen L, Goel A, Grundberg E, Havulinna AS, Ho WK, Hopewell JC, Eriksson N, Kleber ME, Kristiansson K, Lundmark P, Lyytikainen LP, Rafelt S, Shungin D, Strawbridge RJ, Thorleifsson G, Tikkanen E, Van ZN, Voight BF, Waite LL, Zhang W, Ziegler A, Absher D, Altshuler D, Balmforth AJ, Barroso I, Braund PS, Burgdorf C, Claudi-Boehm S, Cox D, Dimitriou M, Do R, Doney AS, Mokhtari NE, Eriksson P, Fischer K, Fontanillas P, Franco-Cereceda A, Gigante B, Groop L, Gustafsson S, Hager J, Hallmans G, Han BG, Hunt SE, Kang HM, Illig T, Kessler T, Knowles JW, Kolovou G, Kuusisto J, Langenberg C, Langford C, Leander K, Lokki ML, Lundmark A, McCarthy MI, Meisinger C, Melander O, Mihailov E, Maouche S, Morris AD, Muller-Nurasyid M, Nikus K, Peden JF, Rayner NW, Rasheed A, Rosinger S, Rubin D, Rumpf MP, Schafer A, Sivananthan M, Song C, Stewart AF, Tan ST, Thorgeirsson G, Schoot CE, Wagner PJ, Wells GA, Wild PS, Yang TP, Amouyel P, Arveiler D, Basart H, Boehnke M, Boerwinkle E, Brambilla P, Cambien F, Cupples AL, de Faire U, Dehghan A, Diemert P, Epstein SE, Evans A, Ferrario MM, Ferrieres J, Gauguier D, Go AS, Goodall AH, Gudnason V, Hazen SL, Holm H, Iribarren C, Jang Y, Kahonen M, Kee F, Kim HS, Klopp N, Koenig W, Kratzer W, Kuulasmaa K, Laakso M, Laaksonen R, Lee JY, Lind L, Ouwehand WH, Parish S, Park JE, Pedersen NL, Peters A, Quertermous T, Rader DJ, Salomaa V, 
Schadt E, Shah SH, Sinisalo J, Stark K, Stefansson K, Tregouet DA, Virtamo J, Wallentin L, Wareham N, Zimmermann ME, Nieminen MS, Hengstenberg C, Sandhu MS, Pastinen T, Syvanen AC, Hovingh GK, Dedoussis G, Franks PW, Lehtimaki T, Metspalu A, Zalloua PA, Siegbahn A, Schreiber S, Ripatti S, Blankenberg SS, Perola M, Clarke R, Boehm BO, O’Donnell C, Reilly MP, Marz W, Collins R, Kathiresan S, Hamsten A, Kooner JS, Thorsteinsdottir U, Danesh J, Palmer CN, Roberts R, Watkins $\mathrm{H}$, Schunkert H, Samani NJ. Large-scale association analysis identifies new risk loci for coronary artery disease. Nat Genet. 2012;45:25-33. The largest meta-analyses to date of GWAS for $C A D$, including a South Asian cohort.

29. Tregouet DA, Konig IR, Erdmann J, Munteanu A, Braund PS, Hall AS, Grosshennig A, Linsel-Nitschke P, Perret C, Desuremain M, Meitinger T, Wright BJ, Preuss M, Balmforth AJ, Ball SG, Meisinger C, Germain C, Evans A, Arveiler D, Luc G, Ruidavets JB, Morrison C, van der HP, Schreiber S, Neureuther K, Schafer A, Bugert P, El Mokhtari NE, Schrezenmeir J, Stark K, Rubin D, Wichmann HE, Hengstenberg C, Ouwehand W, Ziegler A, Tiret L, Thompson JR, Cambien F, Schunkert H, Samani NJ. Genome-wide haplotype association study identifies the SLC22A3-LPAL2-LPA gene cluster as a risk locus for coronary artery disease. Nat Genet. 2009;41:283-285.

30. - Marigorta UM, Navarro A. High trans-ethnic replicability of GWAS results implies common causal variants. PLoS Genet. 2013;9:e1003566. A comprehensive survey of GWAS replicability across 28 diseases demonstrating a strong and significant correlation of Odds Ratios across Europeans and East Asians, indicating that underlying causal variants are common and shared between the two ancestries.

31. Cheng X, Shi L, Nie S, Wang F, Li X, Xu C, Wang P, Yang B, Li Q, Pan Z, Li Y, Xia H, Zheng C, Ke Y, Wu Y, Tang T, Yan X, Yang Y, Xia N, Yao R, Wang B, Ma X, Zeng Q, Tu X, Liao Y, Wang QK. The same chromosome 9p21.3 locus is associated with type 2 diabetes and coronary artery disease in a Chinese Han population. Diabetes. 2011;60:680-4.

32. Hiura Y, Fukushima Y, Yuno M, Sawamura H, Kokubo Y, Okamura T, Tomoike H, Goto Y, Nonogi H, Takahashi R, Iwai $\mathrm{N}$. Validation of the association of genetic variants on chromosome 9 p21 and 1q41 with myocardial infarction in a Japanese population. Circ J. 2008;72:1213-7.

33. Hinohara K, Nakajima T, Takahashi M, Hohda S, Sasaoka T, Nakahara K, Chida K, Sawabe M, Arimura T, Sato A, Lee BS, Ban JM, Yasunami M, Park JE, Izumi T, Kimura A. Replication of the association between a chromosome 9p21 polymorphism and coronary artery disease in Japanese and Korean populations. J Hum Genet. 2008;53:357-9.

34. Shen GQ, Li L, Rao S, Abdullah KG, Ban JM, Lee BS, Park JE, Wang QK. Four SNPs on chromosome 9p21 in a South Korean population implicate a genetic locus that confers high cross-race risk for development of coronary artery disease. Arterioscler Thromb Vasc Biol. 2008;28:360-5.

35. Wang F, Xu CQ, He Q, Cai JP, Li XC, Wang D, Xiong X, Liao YH, Zeng QT, Yang YZ, Cheng X, Li C, Yang R, Wang CC, Wu G, Lu QL, Bai Y, Huang YF, Yin D, Yang Q, Wang XJ, Dai DP, Zhang RF, Wan J, Ren JH, Li SS, Zhao YY, Fu FF, Huang Y, Li QX, Shi SW, Lin N, Pan ZW, Li Y, Yu B, Wu YX, Ke YH, Lei J, Wang N, Luo CY, Ji LY, Gao LJ, Li L, Liu H, Huang EW, Cui J, Jia N, Ren X, Li H, Ke T, Zhang XQ, Liu JY, Liu MG, Xia H, Yang B, Shi LS, Xia YL, Tu X, Wang QK. Genome-wide association identifies a susceptibility locus for coronary artery disease in the Chinese Han population. Nat Genet. 2011;43:345-9.

36. • Lu X, Wang L, Chen S, He L, Yang X, Shi Y, Cheng J, Zhang L, Gu CC, Huang J, Wu T, Ma Y, Li J, Cao J, Chen J, Ge D, Fan Z, Li Y, Zhao L, Li H, Zhou X, Chen L, Liu D, Chen J, Duan X, Hao Y, Wang L, Lu F, Liu Z, Yao C, Shen C, Pu X, Yu L, Fang
X, Xu L, Mu J, Wu X, Zheng R, Wu N, Zhao Q, Li Y, Liu X, Wang M, Yu D, Hu D, Ji X, Guo D, Sun D, Wang Q, Yang Y, Liu F, Mao Q, Liang X, Ji J, Chen P, Mo X, Li D, Chai G, Tang Y, Li X, Du Z, Liu X, Dou C, Yang Z, Meng Q, Wang D, Wang R, Yang J, Schunkert H, Samani NJ, Kathiresan S, Reilly MP, Erdmann J, Peng X, Wu X, Liu D, Yang Y, Chen R, Qiang B, Gu D. Genome-wide association study in Han Chinese identifies four new susceptibility loci for coronary artery disease. Nat Genet. 2012;44:890-4. Largest reported GWAS for CAD in a Chinese Han population demonstrating replication of many European loci and identification of new loci.

37. Takeuchi F, Yokota M, Yamamoto K, Nakashima E, Katsuya T, Asano H, Isono M, Nabika T, Sugiyama T, Fujioka A, Awata N, Ohnaka K, Nakatochi M, Kitajima H, Rakugi H, Nakamura J, Ohkubo T, Imai Y, Shimamoto K, Yamori Y, Yamaguchi S, Kobayashi S, Takayanagi R, Ogihara T, Kato N. Genome-wide association study of coronary artery disease in the Japanese. Eur J Hum Genet. 2012;20:333-40.

38. Lee JY, Lee BS, Shin DJ, Woo PK, Shin YA, Joong KK, Heo L, Young LJ, Kyoung KY, Jin KY, Bum HC, Lee SH, Yoon D, Jung KH, Oh IY, Kim BJ, Lee J, Park SJ, Kim J, Kawk HK, Lee JE, Park HK, Lee JE, Nam HY, Park HY, Shin C, Yokota M, Asano H, Nakatochi M, Matsubara T, Kitajima H, Yamamoto K, Kim HL, Han BG, Cho MC, Jang Y, Kim HS, Euy PJ, Lee JY. A genome-wide association study of a coronary artery disease risk variant. J Hum Genet. 2013;58:120-6.

39. Guo J, Li W, Wu Z, Cheng X, Wang Y, Chen T. Association between $9 \mathrm{p} 21.3$ genomic markers and coronary artery disease in East Asians: a meta-analysis involving 9,813 cases and 10,710 controls. Mol Biol Rep. 2013;40:337-43.

40. Dong L, Wang H, Wang DW, Ding H. Association of chromosome 9p21 genetic variants with risk of coronary heart disease in the East Asian population: a meta-analysis. Ann Hum Genet. 2013;77:183-90.

41. Saleheen D, Alexander M, Rasheed A, Wormser D, Soranzo N, Hammond N, Butterworth A, Zaidi M, Haycock P, Bumpstead S, Potter S, Blackburn H, Gray E, Di AE, Kaptoge S, Shah N, Samuel M, Janjua A, Sheikh N, Haider SR, Murtaza M, Ahmad U, Hakeem A, Memon MA, Mallick NH, Azhar M, Samad A, Rasheed SZ, Gardezi AR, Memon NA, Ghaffar A, Memon FU, Zaman KS, Kundi A, Yaqoob Z, Cheema LA, Qamar N, Faruqui A, Jooma R, Niazi JH, Hussain M, Kumar K, Saleem A, Kumar K, Daood MS, Memon F, Gul AA, Abbas S, Zafar J, Shahid F, Memon Z, Bhatti SM, Kayani W, Ali SS, Fahim M, Ishaq M, Frossard P, Deloukas P, Danesh J. Association of the 9p21.3 locus with risk of first-ever myocardial infarction in Pakistanis: case-control study in South Asia and updated meta-analysis of Europeans. Arterioscler Thromb Vasc Biol. 2010;30:1467-73.

42. IBC 50K CAD Consortium. Large-scale gene-centric analysis identifies novel variants for coronary artery disease. PLoS Genet. 2011;7:e1002260

43. Franceschini N, Carty C, Buzkova P, Reiner AP, Garrett T, Lin Y, Vockler JS, Hindorff LA, Cole SA, Boerwinkle E, Lin DY, Bookman E, Best LG, Bella JN, Eaton C, Greenland P, Jenny N, North KE, Taverna D, Young AM, Deelman E, Kooperberg C, Psaty B, Heiss G. Association of genetic variants and incident coronary heart disease in multiethnic cohorts: the PAGE study. Circ Cardiovasc Genet. 2011;4:661-72.

44. Kral BG, Mathias RA, Suktitipat B, Ruczinski I, Vaidya D, Yanek LR, Quyyumi AA, Patel RS, Zafari AM, Vaccarino V, Hauser ER, Kraus WE, Becker LC, Becker DM. A common variant in the CDKN2B gene on chromosome 9p21 protects against coronary artery disease in Americans of African ancestry. J Hum Genet. 2011;56:224-9.

45. • Lettre G, Palmer CD, Young T, Ejebe KG, Allayee H, Benjamin EJ, Bennett F, Bowden DW, Chakravarti A, Dreisbach A, Farlow 
DN, Folsom AR, Fornage M, Forrester T, Fox E, Haiman CA, Hartiala J, Harris TB, Hazen SL, Heckbert SR, Henderson BE, Hirschhorn JN, Keating BJ, Kritchevsky SB, Larkin E, Li M, Rudock ME, McKenzie CA, Meigs JB, Meng YA, Mosley TH, Newman AB, Newton-Cheh CH, Paltoo DN, Papanicolaou GJ, Patterson N, Post WS, Psaty BM, Qasim AN, Qu L, Rader DJ, Redline S, Reilly MP, Reiner AP, Rich SS, Rotter JI, Liu Y, Shrader P, Siscovick DS, Tang WH, Taylor HA, Tracy RP, Vasan RS, Waters KM, Wilks R, Wilson JG, Fabsitz RR, Gabriel SB, Kathiresan S, Boerwinkle E. Genome-wide association study of coronary heart disease and its risk factors in 8, 090 African Americans: the NHLBI CARe Project. PLoS Genet. 2011;7:e1001300. The largest GWAS of CAD in African Americans, demonstrating lack of replication of CAD loci identified in Europeans and suggesting that no major loci uniquely explain the high prevalence of $C H D$ in African Americans.

46. Wojczynski MK, Li M, Bielak LF, Kerr KF, Reiner AP, Wong ND, Yanek LR, Qu L, White CC, Lange LA, Ferguson JF, He J, Young T, Mosley TH, Smith JA, Kral BG, Guo X, Wong Q, Ganesh SK, Heckbert SR, Griswold ME, O'Leary DH, Budoff M, Carr JJ, Taylor HA Jr, Bluemke DA, Demissie S, Hwang SJ, Paltoo DN, Polak JF, Psaty BM, Becker DM, Province MA, Post WS, O'Donnell CJ, Wilson JG, Harris TB, Kavousi M, Cupples LA, Rotter JI, Fornage M, Becker LC, Peyser PA, Borecki IB, Reilly MP. Genetics of coronary artery calcification among African Americans, a meta-analysis. BMC Med Genet. 2013; $14: 75$.

47. • Carlson CS, Matise TC, North KE, Haiman CA, Fesinmeyer MD, Buyske S, Schumacher FR, Peters U, Franceschini N, Ritchie MD, Duggan DJ, Spencer KL, Dumitrescu L, Eaton CB, Thomas F, Young A, Carty C, Heiss G, Le ML, Crawford DC, Hindorff LA, Kooperberg CL. Generalization and dilution of association results from European GWAS in populations of nonEuropean ancestry: the PAGE study. PLoS Biol. 2013;11:e1001661. In a large multi-ethnic study, the authors demonstrate that although nearly all European risk factor-associated tag SNPs have effects in the same direction across six different ancestries, many have significantly different magnitude of effect (usually lower) in at least one non-European population.

48. Erdmann J, Stark K, Esslinger UB, Rumpf PM, Koesling D, de Wit C, Kaiser FJ, Braunholz D, Medack A, Fischer M, Zimmermann ME, Tennstedt S, Graf E, Eck S, Aherrahrou Z, Nahrstaedt J, Willenborg C, Bruse P, Braenne I, Nothen MM, Hofmann P, Braund PS, Mergia E, Reinhard W, Burgdorf C, Schreiber S, Balmforth AJ, Hall AS, Bertram L, SteinhagenThiessen E, Li SC, Marz W, Reilly M, Kathiresan S, McPherson R, Walter U, Ott J, Samani NJ, Strom TM, Meitinger T, Hengstenberg C, Schunkert H, Assimes TL, Deloukas P, Holm H, Konig IR, Roberts R, Stewart AF. Dysfunctional nitric oxide signalling increases risk of myocardial infarction. Nature. 2013;504:432-6.

49. Humtsoe JO, Feng S, Thakker GD, Yang J, Hong J, Wary KK. Regulation of cell-cell interactions by phosphatidic acid phosphatase 2b/VCIP. EMBO J. 2003;22:1539-54.

50. Strong A, Ding Q, Edmondson AC, Millar JS, Sachs KV, Li X, Kumaravel A, Wang MY, Ai D, Guo L, Alexander ET, Nguyen D, Lund-Katz S, Phillips MC, Morales CR, Tall AR, Kathiresan
S, Fisher EA, Musunuru K, Rader DJ. Hepatic sortilin regulates both apolipoprotein B secretion and LDL catabolism. J Clin Invest. 2012;122:2807-16.

51. Wilson DG, Phamluong K, Li L, Sun M, Cao TC, Liu PS, Modrusan Z, Sandoval WN, Rangell L, Carano RA, Peterson AS, Solloway MJ. Global defects in collagen secretion in a Mia3/ TANGO1 knockout mouse. J Cell Biol. 2011;193:935-51.

52. Erdmann J, Grosshennig A, Braund PS, Konig IR, Hengstenberg C, Hall AS, Linsel-Nitschke P, Kathiresan S, Wright B, Tregouet DA, Cambien F, Bruse P, Aherrahrou Z, Wagner AK, Stark K, Schwartz SM, Salomaa V, Elosua R, Melander O, Voight BF, O’Donnell CJ, Peltonen L, Siscovick DS, Altshuler D, Merlini PA, Peyvandi F, Bernardinelli L, Ardissino D, Schillert A, Blankenberg S, Zeller T, Wild P, Schwarz DF, Tiret L, Perret C, Schreiber S, El Mokhtari NE, Schafer A, Marz W, Renner W, Bugert P, Kluter H, Schrezenmeir J, Rubin D, Ball SG, Balmforth AJ, Wichmann HE, Meitinger T, Fischer M, Meisinger C, Baumert J, Peters A, Ouwehand WH, Deloukas P, Thompson JR, Ziegler A, Samani NJ, Schunkert H. New susceptibility locus for coronary artery disease on chromosome 3q22.3. Nat Genet. 2009;41:280-2.

53. Davies RW, Wells GA, Stewart AF, Erdmann J, Shah SH, Ferguson JF, Hall AS, Anand SS, Burnett MS, Epstein SE, Dandona S, Chen L, Nahrstaedt J, Loley C, Konig IR, Kraus WE, Granger CB, Engert JC, Hengstenberg C, Wichmann HE, Schreiber S, Tang WH, Ellis SG, Rader DJ, Hazen SL, Reilly MP, Samani NJ, Schunkert H, Roberts R, McPherson R. A genome-wide association study for coronary artery disease identifies a novel susceptibility locus in the major histocompatibility complex. Circ Cardiovasc Genet. 2012;5:217-25.

54. Chatterjee TK, Basford JE, Knoll E, Tong WS, Blanco V, Blomkalns AL, Rudich S, Lentsch AB, Hui DY, Weintraub NL. HDAC9 knockout mice are protected from adipose tissue dysfunction and systemic metabolic disease during high-fat feeding. Diabetes. 2014;63:176-87.

55. Kumar J, Yumnam S, Basu T, Ghosh A, Garg G, Karthikeyan G, Sengupta S. Association of polymorphisms in 9 p21 region with CAD in North Indian population: replication of SNPs identified through GWAS. Clin Genet. 2011;79:588-93.

56. Zhou LT, Qin L, Zheng DC, Song ZK, Ye L. Meta-analysis of genetic association of chromosome 9p21 with early-onset coronary artery disease. Gene. 2012;510:185-8.

57. Hinohara K, Ohtani H, Nakajima T, Sasaoka T, Sawabe M, Lee BS, Ban J, Park JE, Izumi T, Kimura A. Validation of eight genetic risk factors in East Asian populations replicated the association of BRAP with coronary artery disease. J Hum Genet. 2009;54:642-6.

58. Reilly MP, Li M, He J, Ferguson JF, Stylianou IM, Mehta NN, Burnett MS, Devaney JM, Knouff CW, Thompson JR, Horne BD, Stewart AF, Assimes TL, Wild PS, Allayee H, Nitschke PL, Patel RS, Martinelli N, Girelli D, Quyyumi AA, Anderson JL, Erdmann J, Hall AS, Schunkert H, Quertermous T, Blankenberg S, Hazen SL, Roberts R, Kathiresan S, Samani NJ, Epstein SE, Rader DJ. Identification of ADAMTS7 as a novel locus for coronary atherosclerosis and association of $\mathrm{ABO}$ with myocardial infarction in the presence of coronary atherosclerosis: two genome-wide association studies. Lancet. 2011;377:383-92. 